\title{
$\widehat{A}$ Madridge \\ madridge Journal of Dentistry and Oral Surgery \\ Interconnecting Scientific World
}

Research Article

Open Access

\section{Part I: Dentinogenic Effect of Magnesium Oxide on Normal Human Dental Pulp Cells: An In Vitro Study}

\author{
Rania M Salem ${ }^{1,2 *}$, Chang Zhang ${ }^{1}$ and Laisheng Chou ${ }^{1}$ \\ ${ }^{\prime}$ Department of Restorative Sciences \& Biomaterials, Goldman School of Dental Medicine, Boston University, Boston, MA 02118, USA \\ ${ }^{2}$ Department of Endodontics, Goldman School of Dental Medicine, Boston University, Boston, MA 02118, USA
}

\section{Article Info}

\author{
*Corresponding author: \\ Rania M Salem \\ Department of Restorative Sciences \& \\ Endodontics \\ Goldman School of Dental Medicine \\ Boston University \\ USA \\ Tel: +3474093109 \\ E-mail: rmsalem@bu.edu
}

Received: October 13, 2021

Accepted: October 28, 2021

Published: November 03, 2021

Citation: Salem RM, Zhang C, Chou L. Part I: Dentinogenic Effect of Magnesium Oxide on Normal Human Dental Pulp Cells: An In Vitro Study. Madridge J Dent Oral Surg. 2021; 6(1): 106-115.

doi: $10.18689 / \mathrm{mjdl}-1000124$

Copyright: ( $) 2021$ The Author(s). This work is licensed under a Creative Commons Attribution 4.0 International License, which permits unrestricted use, distribution, and reproduction in any medium, provided the original work is properly cited.

Published by Madridge Publishers

\begin{abstract}
Due to a limited ability to achieve self-repair and regeneration as well as lack of effective therapeutic options, degeneration and injury of the pulp-dentin complex may result in severe consequences. Magnesium-based biomaterials might provide an innovative therapeutic potential to substantially enhance regeneration of dental tissues. Magnesium $\left(\mathrm{Mg}^{2+}\right)$ has been considered for its potential ability to accelerate proliferation and differentiation of human osteoblasts. However, to date, magnesium oxide (MgO) and its dentinogenic effects on human dental pulp cells (HDPCs) has not been investigated. This study was designed to evaluate the stimulatory effect of different concentrations of $\mathrm{MgO}$ on dentinogenesis of HDPCs. HDPCs were cultured with $0.5 \mathrm{mM}$, $1 \mathrm{mM}, 2 \mathrm{mM}, 4 \mathrm{mM}, 8 \mathrm{mM}$ concentrations of supplemental $\mathrm{MgO}, 0 \mathrm{mM}$ as the negative control group, lignin sulfonic acid sodium salt and xanthan gum as the vehicle control groups. Cell attachment efficiency was assessed at $16 \mathrm{~h}$. Proliferation rate was evaluated at $3,7,10,14$ days. Both attachment efficiency and proliferation rate were assessed by crystal violet staining. Cell viability was determined by activity of mitochondrial dehydrogenase enzyme. Alkaline phosphatase (ALP) activity was assessed using fluorometric assay at 7, 10, and 14 days. Mineralization of cultures was measured by Alizarin Red staining. Statistical analysis was performed using multi-way ANOVA with Wilks' lambda test. Higher cell attachment efficiency was shown with $0.5 \mathrm{mM}$ at 16 hours compared to negative control $(P<0.001)$. Cells with $0.5 \mathrm{mM}$ supplemental $\mathrm{MgO}$ showed significantly higher proliferation rates than negative and vehicle controls at 7 , 10 , and 14 days $(P<0.001)$. Higher levels of ALP activity and mineralization were also observed in $0.5 \mathrm{mM}$ supplemental $\mathrm{MgO}$ at 10 , and 14 days $(P<0.001)$. In conclusion, optimal $\mathrm{MgO}(0.5 \mathrm{mM})$ group significantly upregulated HDPCs attachment, proliferation, ALP activity, odontogenic differentiation and mineralization. Magnesium oxide containing biomaterials could be a potential novel material for pulp and dentin repair in regenerative endodontics.
\end{abstract}

Keywords: Dentinogenesis; Magnesium; Pulp Capping Materials; Regenerative endodontics

\section{Introduction}

Regenerative dentistry represents an attractive multidisciplinary therapeutic approach that counteracts traditional restorative/surgery techniques and benefits from recent advances in materials science, stem cell biology, and molecular biology $[1,2]$. Clinical interventions to treat tooth decay range from simple coronal fillings to invasive tooth root canal treatment [3]. Dental pulp capping is the only available clinical option to maintain pulp vitality in deep lesions, but irreversible pulp inflammation and 
reinfection are frequent outcomes from this treatment [4]. When affected dental pulp involvement is beyond repair, performing endodontic therapy leaves the tooth non-vital and brittle [5]. On-going research strategies have failed to overcome the limitations of existing dental pulp capping materials so that healthy and progressive regeneration of the injured tissues is attained [6]. Preserving pulp vitality is crucial for tooth homeostasis and durability, and thus, there is a critical need for clinical interventions that enable regeneration of the dentin-pulp complex to rescue millions of teeth annually [7]. Pulp vitality is extremely important for tooth viability since it provides nutrition and acts as a biosensor to detect pathogenic stimuli. Moreover, secondary dentin deposition will continue on the preserved vital pulp [4]. It is now accepted that a highly proliferative population of progenitor/stem cells reside within dental pulp [8]. The repair of pulp-dentin complex after vital pulp therapy (VPT) involves the migration and differentiation of dental pulp stem cells (DPSCs) to secondary odontoblasts followed by dentinogenesis and formation of a dentinal bridge sealed on the exposed pulp [9]. In recent years, with the progress of regenerative and molecular approaches, repair of pulp-dentin complex after VPT might be affected by the biological properties of used biomaterials [10-12].

The development of materials with bioregenerative properties is critically important for vital dental pulp therapy and regenerative endodontic procedures [13]. Introducing therapeutic ions with the capacity to induce specific interactions within cells, providing the necessary structural signals, adhesion molecules, for homing, differentiation, and cellular phenotypic conversion, permitting cell-cell and cellmaterial interactions to unlock the innate pathway for selfrepair [14]. Magnesium $\left(\mathrm{Mg}^{2+}\right)$ is considered one of the most ideal biomaterials for such treatment. The cell- $\mathrm{Mg}^{2+}$ interface is a complex and dynamic microenvironment inducing the desired cell functions for dentin regeneration [15]. Several studies have demonstrated that divalent cations such as $\mathrm{Mg}^{2+}$, $\mathrm{Ca}^{2+}$, and $\mathrm{Mn}^{2+}$ play a critical role in tissue remodeling and development $[16,17]$. The extracellular matrix (ECM) of tissue contains certain domains that bind divalent cations. These ECM-bound cations modify the integrin affinity to their respective ligands [18]. Magnesium $\left(\mathrm{Mg}^{2+}\right)$ is essential for numerous biological processes in the human body and is one of the most important ions associated with biological apatites: as dentin and bone are composed by $1.11 \mathrm{wt} \%$ and $0.47 \mathrm{wt} \%$ of $\mathrm{Mg}^{2+}$, respectively [19]. $\mathrm{Mg}^{2+}$ is known to stimulate osteoblast proliferation, differentiation, migration, and mineralization ability $[20,21] . \mathrm{Mg}^{2+}$ is involved in biomineralization of bones and teeth and directly affects crystallization and pattern generation of the inorganic mineral phase $[19,22]$. The positive effects of $\mathrm{Mg}^{2+}$ in terms of bone and dentin generation are witnessed by their diffused presence as dopants in hydroxyapatite and other calciumphosphate based systems. [23,24]. Magnesium oxide (MgO), another kind of inorganic filler, with enhanced biocompatibility and non-toxic biological activity, became a research hotspot of polymer modification [25]. It releases $\mathrm{Mg}^{2+}$ ions when dissolving, favorable for a variety of enzymes conducive to the activation and synthesis of proteins. Moreover, its unique biological activity plays an important role in cell viability, improving the survival rate of cells as well as the activity of composites [26]. Additionally, $\mathrm{MgO}$ also performs as an alkaline degradable material with excellent biological characteristics for tissue regeneration [27]. Several studies showed that $\mathrm{MgO}$-modified glass was able to exert a strong stimulating effect on cell growth, thus confirming the beneficial bioactive effect of $\mathrm{Mg}^{2+}$. $\mathrm{MgO}$-scaffolds also served as a source of soluble ions when placed in contact with bone marrow mesenchymal stromal cells (BMMSC), promoting cell proliferation, differentiation, and providing a desirable microenvironment to facilitate bone biomineralization [28].

This is the first research investigating the dentinogenic effect of magnesium oxide on normal human dental pulp cells. Thus, the objective in the present study was to comprehensively: 1- investigate the dose-dependent effects of $\mathrm{MgO}$ on cell attachment, proliferation, differentiation and biomineralization on normal human dental pulp cells (HDPCs) in vitro. 2- To establish an optimal concentration of $\mathrm{MgO}$ that could ultimately be used to develop a new dental pulp capping material additive which may contribute to a better understanding of the influence of $\mathrm{MgO}$ on pulp regeneration and its potential application as a promising material for clinical pulp regenerative therapy.

\section{Materials and Methods}

\section{Preparation of concentrated magnesium oxide suspension}

Magnesium oxide (Mag Chem 10, Martin Marietta Magnesia Specialties, Baltimore, MD, USA) powder milled size ranging from 44 to 297 micron. An aqueous magnesium oxide suspension was prepared based on the combined weight of water, lignin sulfonic acid sodium salt (anti-hydration agent) and xanthan gum (suspension aid), providing a highly stable concentrated suspension (according to the patent developed by Richard Van De Walle 1989) [29]. Five stock solutions were prepared at concentrations of $5 \mathrm{mM}, 10 \mathrm{mM}, 20 \mathrm{mM}, 40 \mathrm{mM}$ and $80 \mathrm{mM}$ respectively.

\section{Lignosulfonic acid sodium salt and xanthan gum solvent preparation}

Lignosulfonic acid sodium salt and xanthan gum (Sigma Aldrich, Burlington, MA, USA) dissolved in deionized water subsequently filtered under sterile condition in the biological hood, kept in a labeled container and stored at room temperature, utilized as vehicle controls to be compared to the negative control.

\section{Human dental pulp cell (HDPC) culture}

Human dental pulp explants were isolated from freshly extracted third molar collected from young and systemically healthy patients from 15-25 years old patients under Boston University IRB approval $\mathrm{H}-33173$. All patients undergoing a routine third molar extraction at the oral surgery clinic at Boston university. Human dental pulp cells (HDPCs) were isolated following a previously published protocol with modifications [30]. Teeth were split open with a \#7 chandler 
bi-bevel bone chisel and hammer, and the exposed dental pulp explants were transferred immediately into a $25 \mathrm{~cm}^{2}$ culture flask (Thermo Fisher Scientific, Cambridge, MA, USA). Culture medium consisted of $10 \%$ fetal bovine serum (FBS) (R\&D Systems, Minneapolis MN, USA), Penicillin antibiotic $(100 \mathrm{U} / \mathrm{mL})$, and Streptomycin $(100 \mathrm{ug} / \mathrm{mL})$ (Gibco, Waltham, MA, USA), Amphotericin B anti-fungal $(0.25 \mathrm{ug} / \mathrm{ml})$ in Basal Eagle's Medium (BME), (Gibco, Waltham, MA, USA). All tissues were maintained at $37^{\circ} \mathrm{C}$, in a standard $5 \% \mathrm{CO}_{2}$ and saturated humidity incubator and cultured up to the second passage. The culture medium was replaced every 3 days until the cells reached $80 \%$ confluence. The cells were then detached from the flask using 0.05\% Trypsin-EDTA (Gibco, Waltham, MA, USA) and centrifuged (TJ-6 Beckman Centrifuge) for 5 min at $1000 \mathrm{rpm}$. The cells collected in the pellet were resuspended, counted using a hemocytometer and utilized in the experiment. Characterization of dentinogenic phenotype of the cells was confirmed by expression of dentinogenic markers induced by vitamin $D_{3}$ stimulation. Human dental pulp cells were transferred to 24 well plates (Thermo Fisher Scientific, Cambridge, MA,USA) and grown in culture medium supplemented with $0 \mathrm{mM}$ (control), $0.5 \mathrm{mM}, 1 \mathrm{mM}, 2 \mathrm{mM}, 4$ $\mathrm{mM}, 8 \mathrm{mM}$ magnesium oxide ( $\mathrm{MgO}$ ) concentration groups, and vehicle controls (lignin sulfonic acid sodium salt, and xanthan gum) respectively. For differentiation and mineralization studies, growth media were replaced with preinductive dentinogenic media for a total of 72 hours before each predetermined time intervals: 7, 10, and 14 days. Dentinogenic media consisted of the following: $10 \%$ charcoal stripped fetal bovine serum (FBS) (Life Technologies, Waltham, MA,USA), $100 \mathrm{U} / \mathrm{ml}$ Penicillin (Gibco, Waltham, MA, USA), 100 $\mu \mathrm{g} / \mathrm{mL}$ streptomycin (Gibco Waltham, MA, USA), $10^{-8} \mathrm{M}$ Menadione (Sigma Aldrich, Burlington, MA, USA), $10 \mathrm{mM}$ $\beta$-Glycerophosphate (Sigma Aldrich, Burlington, MA, USA), $0.05 \mathrm{mg} / \mathrm{mL} \mathrm{L}$-ascorbic acid (Sigma Aldrich, Burlington, MA,USA), 2 mM L-glutamine (Gibco, Waltham, MA, USA). The next day, cells were cultured in pre-inductive dentinogenic media with the addition of $10 \mathrm{nM}$ Vitamin $\mathrm{D}_{3}(172 \mathrm{~g} / \mathrm{mol})$ (Sigma Aldrich, Burlington, MA, USA) for a total of 48 hours before the predetermined time intervals. Supernatant fluid was collected on days 7, 10, and 14. Alkaline phosphatase (ALP) activity was measured in the collected supernatants. The remaining fixed cells on the culture plates were used to perform the mineralization assay.

\section{Assessment of human dental pulp cells (attachment efficiency) and proliferation rates}

Cell attachment efficiency was assessed at $16 \mathrm{~h}$. HDPCs were seeded in 24-well plates (Thermo Fisher Scientific, Cambridge, MA, USA). at a density of two hundred thousand $\left(2 \times 10^{5}\right)$ cells per well. The cells were seeded with basal medium eagle (BME, Gibco, Waltham, MA, USA). culture medium supplemented with $0 \mathrm{mM}$ (control), $0.5 \mathrm{mM}, 1 \mathrm{mM}$, $2 \mathrm{mM}, 4 \mathrm{mM}, 8 \mathrm{mM}$ magnesium oxide (MgO) concentration groups, and vehicle controls (lignin sulfonic acid sodium salt, and xanthan gum) respectively. After 16 hours, the medium was discarded, and the wells were washed 3 times with phosphate-buffered saline (PBS) (Gibco, Waltham, MA, USA). Thereafter, the cells were fixed by adding $500 \mu \mathrm{L}$ of $10 \%$ neutral buffered formalin (Sigma-Aldrich, Burlington, MA, USA) for $1 \mathrm{~h}$ at room temperature. The fixed cells were then stained by adding $500 \mu \mathrm{L}$ of $0.2 \%$ crystal violet stain (Sigma-Aldrich, Burlington, MA, USA) for another hour. Afterward, all wells were washed 3 times using PBS to remove any unbound stains. The density of the stained cells was measured by the spectrophotometer (TECAN, Infinite 200 Pro) at wavelength $590 \mathrm{~nm}$. Cell proliferation was monitored at 16 hours, 7 days, 10 days, and 14 days. The cells were seeded in 24-well plates at a density of three thousand $\left(3 \times 10^{3}\right)$ per well. After an optimal attachment was achieved in each well and before the first round of proliferation, i.e., after $16 \mathrm{~h}, 100 \mu \mathrm{L}$ of magnesium oxide (MgO) groups, and vehicle controls were added at the same concentrations as mentioned above. The culture plates were incubated under $37^{\circ} \mathrm{C}, 5 \% \mathrm{CO} 2$ and growth media were changed every 3 days. On each time point, the cells were fixed and stained following the same protocol used in the attachment experiment. The optical density of each group at each point of time was compared to the optical density of $3 \times 10^{3}$ cells at $16 \mathrm{~h}$ as a baseline to determine the proliferation rates. The optical density of the crystal violet stain is directly proportional to the attached cell numbers.

\section{Assessment of human dental pulp cells (HDPCS) cell viability}

Human Dental Pulp cells (HDPCs) were seeded at a density of 300 cells per well in $100 \mu \mathrm{L}$ of cell culture media in a 96 -well plate. Cells were incubated for $16 \mathrm{hr}$ at $37^{\circ} \mathrm{C}, 5 \%$ $\mathrm{CO}_{2}$. Cellular viability was measured via 3-(4,5-dimethylthiazol2-yl)-2, 5-diphenyltetrazolium bromide (MTT). Ab211091 Cell Cytotoxicity Assay Kit (Abcam, Waltham, MA, USA). As in the proliferation experiment, after $16 \mathrm{~h}, 100 \mu \mathrm{L}$ of cell culture media containing supplemental magnesium oxide $(\mathrm{MgO})$ in the concentrations $0.5 \mathrm{mM}, 1 \mathrm{mM}, 2 \mathrm{mM}, 4 \mathrm{mM}, 8 \mathrm{mM}, 0 \mathrm{mM}$ as negative control, lignin sulfonate and xanthan gum as vehicle controls were added to the cells. Culture medium for the both the control and experimental groups was changed by a fresh one every 3 days. Cell viability was assessed by measuring mitochondrial succinic dehydrogenase (SDH) activity at 16 hours, 3, 7, 10 and 14 days. At each required time point, growth media was removed, $50 \mu \mathrm{L}$ of serum free media and $50 \mu \mathrm{L}$ of 3-[4,5-dimethylthiazole-2-yl]-2,5diphenyltetrazolium bromide (MTT) Reagent was added to each well. For background control wells, $50 \mu \mathrm{L}$ of MTT Reagent and $50 \mu \mathrm{L}$ cell culture media was added. The plates were incubated at $37^{\circ} \mathrm{C}$ for 3 hours. After incubation, the MTT Reagent supplemented media was removed. $150 \mu \mathrm{L}$ of MTT solvent was added into each well. The mitochondria in viable cells can transform the tetrazolium into a purple-colored compound called formazan [31]. The absorbance reading of the produced purple formazan of each group was recorded at wavelength $590 \mathrm{~nm}$ using the microplate reader. The data then were plugged into the following equation to calculate the percentage of cytotoxicity for each group: \% Cytotoxicity $=100 \times($ Control-Sample $) /$ Control 


\section{Assessment of human dental pulp cells (HDPCS) alkaline phosphatase (ALP) differentiation marker activity}

Supernatants collected at days 7,10 and 14 were utilized. An alkaline phosphatase (ALP) fluorometric assay kit (Abcam, Waltham, MA, USA) was used to measure alkaline phosphatase activity in the cell culture supernatants according to the manufacturer's instructions. $100 \mu \mathrm{L}(10 \mathrm{x}$ diluted) culture supernatants were incubated with $20 \mu \mathrm{L}$ of the non-fluorescent 4-methylumbelliferone phosphate disodium salt (MUP substrate) in a 96 well black plate with clear bottom (Thermo Fisher Scientific, Cambridge, MA, USA). MUP was converted into fluorescent 4-Methylumbelliferone (4-MU) when dephospholated by ALP. The plates were incubated for 30 minutes and protected from light. Thereafter, the reaction was terminated by $20 \mu \mathrm{L}$ stop solution, which was added to all wells, except for the blank control, followed by gentle shaking of the plate. The emission of the fluorescent 4-MU was then measured at 440nm by excitation at $360 \mathrm{~nm}$ on the spectrophotometer. ALP activities were calculated by a standard curve and normalized to ALP activity on a per million cell bases.

\section{Assessment of human dental pulp cells (HDPCS) mineralization}

The attached cells in the 24 well plates at days 7, 10, and 14 were used. The crystal violet stain was removed from the plates by adding Triton-X 1\% (v/v) $(1.2 \mathrm{~mL})$. The 24 well plates were placed on a shaker for $30 \mathrm{~min}$ at room temperature. The plates were washed cautiously four times with $1 \mathrm{ml}$ deionized water to the point where they are colorless. Mineralization was examined through measuring the accumulation of calcium deposition. $1 \mathrm{~mL}$ of $40 \mathrm{mM}$ Alizarin Red S staining (Sigma Aldrich, Burlington, MA, USA) ( $\mathrm{pH} 4.3$ ) solution, was added to the plates. Cells were incubated at room temperature in the dark for $45 \mathrm{~min}$. Alizarin Red S staining solution was then carefully aspirated, and the plates were washed for four times with $1 \mathrm{ml}$ distilled water until clear. Finally, spectrophotometer at a wavelength of $405 \mathrm{~nm}$ was used to measure the absorbance. Each condition was normalized to a per million cell bases.

\section{Statistical analysis}

All experiments were performed in six replicates. Descriptive statistics is presented in tables (1-9). The means and standard deviations (SD) of human dental pulp cell attachment efficiency and proliferation rates at 16 hours, 7 , 10 , and 14 days were calculated, in addition to levels of dentinogenic differentiation marker ALP and mineralization at 7,10 , and 14 days. Differentiation and mineralization data were normalized on a per million cells basis at 7, 10, and 14 days. Statistical analysis was performed using software JMP Pro 13 (ver. 13.1.0). Multi-Way Analysis of Variance (MultiWay ANOVA) with Wilks' lambda test is used for statistical analysis between the groups. Differences at $P \leq 0.05$ were considered statistically significant.

\section{Results}

\section{Effect of supplemental MgO on cell attachment efficiency of HDPCS at various concentrations}

Adherence of HDPCs on culture wells occurred within few hours after seeding of $2 \times 10^{6}$ cells per well on 24-well plates containing culture media supplemented with different $\mathrm{MgO}$ concentrations $0.5 \mathrm{mM}, 1 \mathrm{mM}, 2 \mathrm{mM}, 4 \mathrm{mM}, 8 \mathrm{mM}$ and $0 \mathrm{mM}$ as the negative control group, and lignin sulfonic acid sodium salt and xanthan gum as vehicle control groups. Analysis for cell attachment efficiency was performed as a baseline after 16 hours from cell seeding. Based on the observation results cell attachment of $\mathrm{MgO}$ on tissue culture plates was significantly greater in the $0.5 \mathrm{mM}$ supplemental concentrations compared to the other groups and the negative control $(P<0.001)$ after 16 hours (figure 1) (table 1). Similarly, the data showed a noted increase in cell attachment for the vehicle control groups lignin sulfonic acid sodium salt and xanthan gum compared to the negative control. Regarding, $\mathrm{MgO}$ concentrations higher than $0.5 \mathrm{mM}$ concentration groups cell attachment was significantly lower than that of the negative control $(P<0.001)$ (figure 1$)$. It was observed that within this time period, $0.5 \mathrm{mM} \mathrm{MgO}$ was the only tested concentration significantly enhancing cell attachment efficiency when compared to the negative control.

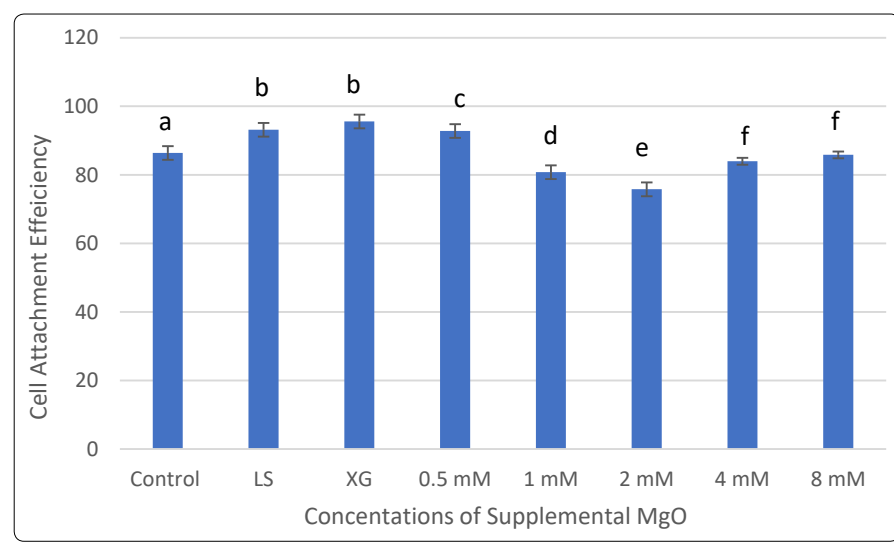

Figure 1: Bar graph showing Cell Attachment Efficiency at 16 hours of all Magnesium Oxide (MgO) Concentrations.

Notes: Normal human dental pulp cells were cultured for 16 hours with media containing supplemental magnesium oxide (MgO) concentrations: $0.5 \mathrm{mM}, 1 \mathrm{mM}, 2 \mathrm{mM}, 4 \mathrm{mM}, 8 \mathrm{mM}, 0$ $\mathrm{mM}$ as the control group, lignin sulfonate and xanthan gum (vehicle controls). Different letters indicate a significant difference between groups $(P<0.001)$ compared to the control in each condition at the specified time point. Error bars indicate the standard deviations of six replicates.

Table 1: P-Values of Cell Attachment Efficiency of Magnesium Oxide (MgO) at 16 hours $(P<0.001)$

\begin{tabular}{|l|l|l|l|l|}
\hline Value & Exact F & NumDF & DenDF & Prob $>$ F \\
\hline 8.7991515 & 37.1520 & 9 & 38 & $<.001^{*}$ \\
\hline
\end{tabular}

\section{Effect of Supplemental MgO on Proliferation rate of HDPCs at various concentrations}

The proliferation rate of HDPCs at 7,10 , and 14 days showed a statistically significant increase in the $0.5 \mathrm{mM}$ supplemental $\mathrm{MgO}$ concentration group compared to the negative control group $(p<0.001)$ (figure 2) (table 2). Meanwhile, for $\mathrm{MgO}$ concentration groups higher than 0.5 $\mathrm{mM}$ the cell proliferation rates decreased significantly $(p<0.001)$. Regarding the lignin sulfonic acid sodium salt and 
xanthan gum vehicle control groups, there were no significant differences in their proliferation rate compared to the negative control (figure 2). Wilks' Lambda interaction P- value for MgO concentrations and their proliferation rates at these time intervals ( 7 , and 10 days) showed a statistically significant value $(p<0.001)$ (table 3$)$. The trend of the presented results during the whole assay as seen in (figure 2) showed that the $0.5 \mathrm{mM} \mathrm{MgO}$ concentration result was significant at all the tested time intervals $7,10,14$ days.

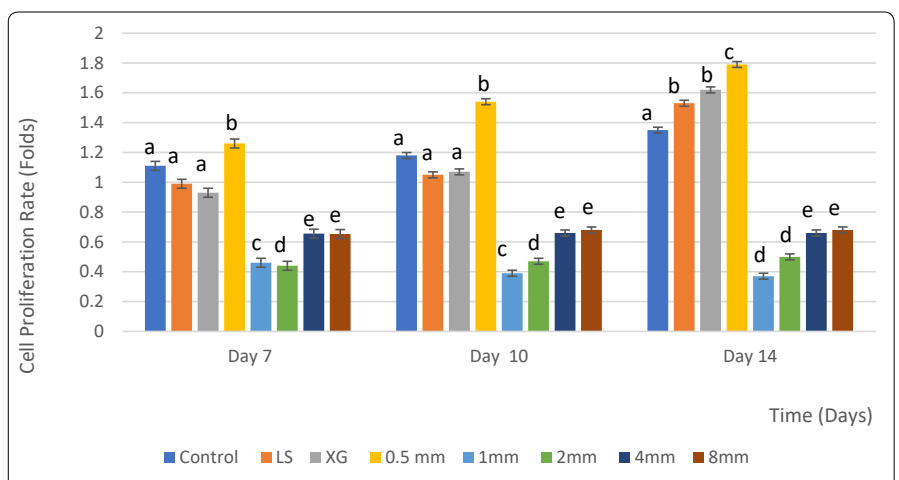

Figure 2: Bar graph showing Proliferation rates of normal human dental pulp cells in media with tested supplemental magnesium oxide (MgO) concentrations: $0.5 \mathrm{mM}, 1 \mathrm{mM}, 2 \mathrm{mM}, 4 \mathrm{mM}, 8 \mathrm{mM}, 0 \mathrm{mM}$ as the control group, lignin sulfonate and xanthan gum as the vehicle controls for time periods of $7,10,14$ days.

Notes: Different letters indicate a significant difference between groups $(P<0.001)$ compared to the control in each condition at the specified time point. Error bars indicate the standard deviations of six replicates.

Table 2: P-Values of Proliferation Rate within Groups for Multi Way ANOVA (MANOVA) of Magnesium Oxide $(\mathrm{MgO})$ Concentrations $(P<0.001)$

\begin{tabular}{|l|l|l|l|l|l|}
\hline Test & Value & Exact F & Num DF & Den DF & Prob >F \\
\hline F Test & 86.787207 & 347.1488 & 9 & 36 & $<.0001^{*}$ \\
\hline
\end{tabular}

Table 3: Wilks' Lambda Interaction P-Values for Magnesium Oxide (MgO) Proliferation Rate at Different Time Intervals $(P<0.001)$

\begin{tabular}{|l|l|l|l|l|l|}
\hline Test & Value & Approx. F & Num DF & Den DF & Prob >F \\
\hline Wilks' Lambda & 0.0192645 & 6.5100 & 36 & 125.4 & $<.001^{*}$ \\
\hline
\end{tabular}

\section{Effect of supplemental MgO on cell viability of HDPCs at various concentrations}

SDH activity presented $42.46 \%$, and $44.79 \%$ at 16 hours, $77.58 \%$, and $82 \%$ at day $3,79.00 \%$ and $78.42 \%$ at day 7 , $80.56 \%$ and $85.79 \%$ at day 10 , and $95.65 \%, 95.82 \%$ at day 14 in vehicle control groups lignin sulfonic acid sodium salt and xanthan gum compared to the negative control $(p<0.001)$ (figure 3). For the $0.5 \mathrm{mM} \mathrm{MgO}$ concentration, the SDH activity value showed $44.50 \%$ at 16 hours, $73.58 \%$ at day $3,81.07 \%$ at day $7,84.06 \%$ at day 10 , and $92.98 \%$ at day 14 . SDH activity values showed a statistically significant increase with time $(p<0.0001$ ) (figure 3) (table 4). However, for the $1 \mathrm{mM}, 2 \mathrm{mM}$, $4 \mathrm{~mm}$ and $8 \mathrm{mM}$ supplemental $\mathrm{MgO}$ concentrations, SDH activity showed a significant decrease at 16 hours, days 3,7 , 10 , and 14 in comparison with the negative control and vehicle controls $(p<0.001)$ (figure 3 ). Wilks' Lambda interaction $\mathrm{P}$-value for supplemental $\mathrm{Mg}^{2+}$ concentrations and cellular activity showed a statistically significant value $(p<0.001)$
(Table 5).

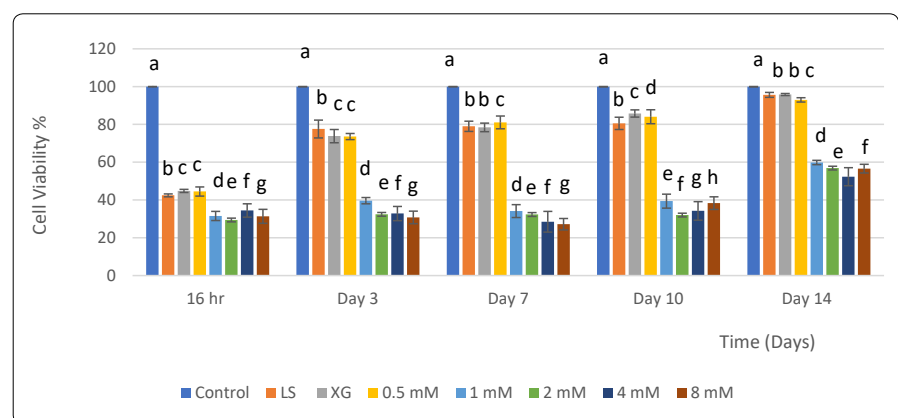

Figure 3: Bar graph showing Cell Viability of normal human dental pulp cells in media with tested supplemental magnesium oxide $(\mathrm{Mg} 0)$ concentrations: $0.5 \mathrm{mM}, 1 \mathrm{mM}, 2 \mathrm{mM}, 4 \mathrm{mM}, 8 \mathrm{mM}, 0 \mathrm{mM}$ as the control group, lignin sulfonic acid sodium salt and xanthan gum vehicle control groups for time periods of 16 hours 3, 7, 10, 14 days.

Notes: Different letters indicate a significant difference between groups $(P<0.001)$ compared to the control in each condition at the specified time point. Error bars indicate the standard deviations of six replicates.

Table 4: P- values of Cell Viability within Groups for Multi Way ANOVA (MANOVA) of Magnesium Oxide $(\mathrm{MgO})$ Concentrations $(P<0.001)$

\begin{tabular}{|l|l|l|l|l|l|}
\hline Test & Value & Exact F & Num DF & Den DF & Prob $>$ F \\
\hline F Test & 395.49121 & 966.7563 & 9 & 22 & $<.001^{*}$ \\
\hline
\end{tabular}

Table 5: Wilks' Lambda Interaction P-Values for Magnesium Oxide (MgO) Cell Viability at Different Time Intervals $(P<0.001)$

\begin{tabular}{|l|l|l|l|l|l|}
\hline Test & Value & Approx. F & Num DF & Den DF & Prob >F \\
\hline Wilks' Lambda & $1.0685 e-6$ & 77.4180 & 36 & 72.939 & $<.001^{\star}$ \\
\hline
\end{tabular}

\section{Effect of MgO on alkaline phosphataseactivity (ALP) of HDPCs at various concentrations}

Enzymatic activity of alkaline phosphatase on HDPCs was analyzed. A significant increase was noted in the $0.5 \mathrm{mM}$ supplemental $\mathrm{MgO}$ concentration group $(P<0.001)$ at all time intervals compared to all control groups (figure 4) (table 6) in 0.5 $\mathrm{mM} \mathrm{MgO}$ concentration group, there were also significant timedependent increase of ALP activity $(P<0.001)$. For other $\mathrm{MgO}$ concentration groups higher than $0.5 \mathrm{mM}$, results of alkaline phosphatase (ALP) activity were comparable to the negative control with a statistically significant difference $(P<0.001)$. Wilks' Lambda interaction P-value for supplemental $\mathrm{MgO}$ concentrations and their alkaline phosphatase activity demonstrated a statistically significant value $(p<0.001)$ (Table 7).

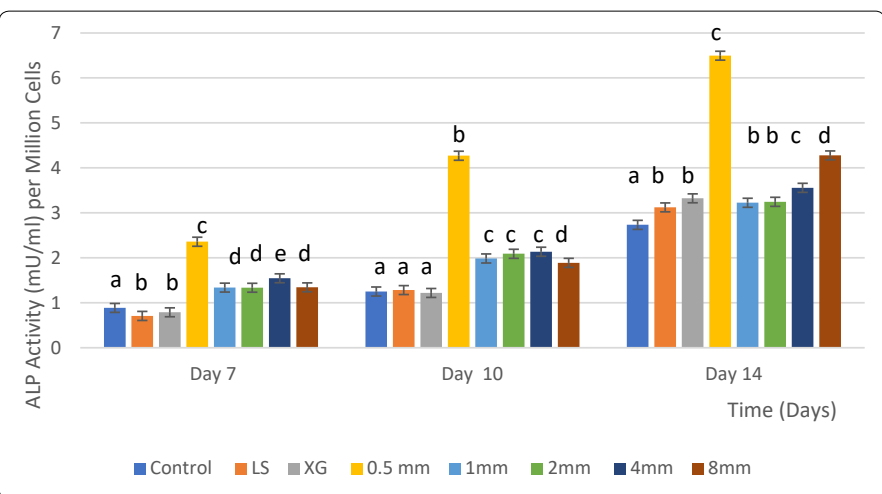

Figure 4: Bar graph showing Alkaline phosphatase activity of normal human pulp cells in media supplemented with magnesium oxide ( $\mathrm{MgO}$ ) concentrations $0.5 \mathrm{mM}, 1 \mathrm{mM}, 2 \mathrm{mM}, 4 \mathrm{mM}, 8 \mathrm{mM}$ and $0 \mathrm{mM}$ as control group, lignin sulfonate and xanthan gum vehicle controls for time periods of $7,10,14$ days. Alkaline phosphatase activity in supernatants was 
normalized permillion cells at each time interval. The control cells were treated with growth media without supplemental magnesium oxide.

Notes: Different letters indicate a significant difference between groups $(P<0.001)$ compared to the control in each condition at the specified time point. Error bars indicate the standard deviations of six replicates.

Table 6: P-values with in Groups for Multi-way ANOVA (MANOVA) for Alkaline Phosphatase (ALP) Activity of Magnesium Oxide (MgO) Concentrations $(<0.001)$

\begin{tabular}{|l|l|l|l|l|l|}
\hline Test & Value & Exact F & Num DF & Den DF & Prob $>$ F \\
\hline F Test & 112.94043 & 476.8596 & 9 & 38 & $<.001^{*}$ \\
\hline
\end{tabular}

Table 7: Wilks' Lambda for the interaction P-values of Magnesium Oxide Alkaline Phosphatase (ALP) Activity at Different Time Intervals $(P<0.001)$

\begin{tabular}{|l|l|l|l|l|l|}
\hline Test & Value & Approx. F & Num DF & Den DF & Prob $>$ F \\
\hline Wilks' Lambda & 0.0131025 & 31.8044 & 18 & 74 & $<.001^{*}$ \\
\hline
\end{tabular}

\section{Effect of MgO on Mineralization rate of HDPCs at various concentrations}

Mineralization of differentiating odontoblasts was measured by Alizarin Red $S$ staining. At each of all-timeintervals, the $0.5 \mathrm{mM}$ supplemental $\mathrm{MgO}$ concentration group showed a statistically higher mineralization rate compared to the negative control group and vehicle control groups $(p<$ 0.001). In $0.5 \mathrm{mM} \mathrm{MgO}$ concentration group, there were also significant time-dependent increase of mineralization rates $(P<0.001)$ (table 8$)$. In comparison to the $0.5 \mathrm{mM} \mathrm{MgO}$ concentration group, other higher $\mathrm{MgO}$ concentration groups showed significantly lower mineralization rates $(P<0.001)$ (figure 5). $\mathrm{MgO}$ concentration groups higher than $0.5 \mathrm{mM}$ showed slightly lower mineralization rates at days 10 and 14 comparable to the negative control and vehicle control groups lignin sulfonic acid sodium salt and xanthan gum. Wilks' Lambda interaction P-value for supplemental $\mathrm{MgO}$ concentrations and their mineralization rates demonstrated a statistically significant value $(p<0.001)$ (Table 9$)$.

Table 8: P-Values with in Groups for Multi way- ANOVA (MANOVA) of Mineralization Rate of Magnesium Oxide $(\mathrm{MgO})$ Concentrations $(P<0.001)$

\begin{tabular}{|l|l|l|l|l|l|}
\hline Test & Value & Exact $\mathbf{F}$ & Num DF & DenDF & Prob $>$ F \\
\hline F Test & 337.21238 & 1559.6072 & 8 & 37 & $<.001^{*}$ \\
\hline
\end{tabular}

Table 9: Wilk's Lambda for the interaction P-values of MagnesiumOxide $(\mathrm{MgO})$ Mineralization Rate at Different Time Intervals $(P<0.001)$

\begin{tabular}{|l|l|l|l|l|l|}
\hline Test & Value & Approx. F & Num DF & Den DF & Prob $>$ F \\
\hline Wilks' Lambda & 0.0004423 & 209.4636 & 16 & 72 & $<.001^{*}$ \\
\hline
\end{tabular}

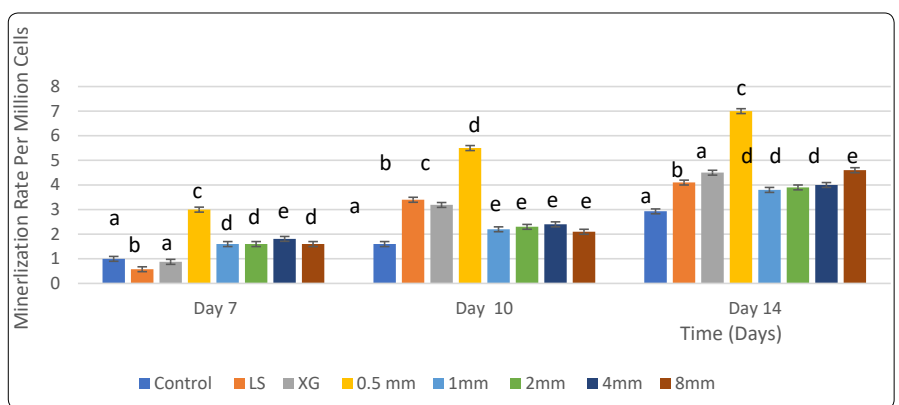

Figure 5: Bargraph showing mineralization rate of human dental pulp cells in media supplemented with magnesium oxide $(\mathrm{MgO})$ concentrations 0.5

$\mathrm{mM}, 1 \mathrm{mM}, 2 \mathrm{mM}, 4 \mathrm{mM}, 8 \mathrm{mM}$ and $0 \mathrm{mM}$ as control group, lignin sulfonate and xanthan gum (vehicle controls) for time periods of $7,10,14$ days.

Mineralization of fixed cell samples was measured by spectroscopic analysis at $405 \mathrm{~nm}$ and normalized per million cells at each time interval. The control cells were treated with growth media without supplemental magnesium oxide.

Notes: Different letters indicate a significant difference between groups $(P<0.001)$ compared to the control in each condition at the specified time point. Error bars indicate the standard deviations of six replicates.

\section{Discussion}

Maintenance of vitality of the dental pulp and stimulation of the remaining pulp tissue for adequate structural/functional healing of the pulp-dentin complex have been the goal for a successful long-term restorative dental treatment [32]. Progress in dentistry is associated with advancements in dental materials and the design of new regenerative therapies. Regenerative therapy using human dental pulp stem cells (HDPSCs) is currently acquiring interest because of the potential of these cells to differentiate into odontoblasts and osteoblasts [33], both of which have the ability to replace injured bone and dentin pulp tissues with healthy tissue and thus restore functionality of the tooth [34]. In the present study, human dental pulp cells (HDPCs), with physiological properties which are homologous to the primary tissue where the endodontic materials come in contact were used. HDPCs have other advantages such as a large capacity for proliferation, the ability to maintain their cellular phenotype, and the sensitivity of response to toxins [35]. For the abovementioned reasons, HDPCs can be considered a clinically relevant cellular model to evaluate the effect of endodontic materials. On the other hand, the choice of the material for dental pulp capping in dental treatment is critical in treating damaged pulpal tissues with the principal objective of promoting regeneration of the dentin bridge through dentinogenesis [32]. The fundamental characteristics of these dental materials are their biocompatibility, cytocompatibility, antibacterial capacity and properties that induce tissue healing; and ability to seal the lesion [35]. Some of the commonly used materials for dental capping include; calcium hydroxide $(\mathrm{CaOH} 2)$, mineral trioxide aggregate (MTA), calcium silicate-based, bioceramics, resin modified calcium silicate, adhesive resins, and Growth Factors. Unfortunately, none of these materials/products have been able to meet all the requirements of an ideal vital pulp therapy with long term clinical outcome [36]. It has been shown in the literature that therapeutic ions such as lithium, magnesium, strontium and zinc enhance osteogenic differentiation of mesenchymal stem cells, regulating osteoblast mediated bone formation [37]. There is a great hope in employing $\mathrm{Mg}^{2+}$ ions in regenerative pulp therapy through their ability to mobilize endogenous cells and to regulate the proliferation and differentiation of HDPCs. The introduction of bioactive $\mathrm{MgO}$ as an alternative $\mathrm{Mg}^{2+}$ ion supply might explore the potential to overcome challenges of dentinogenesis. Therefore, the main target of the present paper was to determine the effects of different concentrations of supplemental MgO on HDPCs 
in terms of cell attachment, proliferation, differentiation, and mineralization to establish an optimal concentration to develop a novel pulp capping material.

Cell adhesion supports tissue morphogenesis as well as tissue repair. Cellular interactions between osteoblasts and the biomaterial surface are thought to be mediated primarily by membrane-associated adhesion receptors belonging to the integrin super family $[38,39]$. Previous studies found that $\mathrm{Mg}^{2+}$ enhanced the chondrogenesis of mesenchymal stem cells (MSCs) through integrins [40-45]. A number of studies have also shown that binding of integrins to extracellular matrix proteins results in the activation of signaling pathways including those which result in tyrosine phosphorylation of focal adhesion kinase (FAK; pp125 FAK) in osteoblasts and other cell types [44,45]. In a study by reported significantly enhanced expression of various integrin family members $\beta 1-, \alpha 5 \beta 1, \alpha 3 \beta 1$, when human bone-derived cells (HBDCs) were grown on $\mathrm{MgO}$ modified alumina compared with $\mathrm{MgO}$ free. Spreading of HBDCs was more pronounced with redistribution of $\alpha 5 \alpha 1$-integrin receptor, and maximal localization at points of contact was also noted [46]. These findings suggested that the supplemental $\mathrm{MgO}$ might also deliver its effect on the attachment of HDPCs. In the present study, the results showed that the highest attachment was noticed in the $0.5 \mathrm{mM} \mathrm{MgO}$ concentration. These results may be attributed to the possible mechanisms, by which surface chemistry modification of MgO triggers HDPCs, suggesting that tyrosine phosphorylation of signaling proteins was enhanced affecting cellular adhesion. In a study by [47], human dental pulp stem cells when placed in contact with chitosan scaffolds were not able to attach nor spread on the surface since chitosan lacks adhesion motifs. Additionally, [48] investigated the effect of magnesium hydroxyapatite whiskers/ poly (D, L-lactide) (MgHAp-Ws/PDLLA) composite films on the adhesion of osteoblast like cells (MC3T3-E1). MC3T3-E1 cells cultured on the Mg-HApWs/PDLLA films had better adhesion and spreading compared with the magnesium free HAp-Ws/PDLLA films. Such enhancement on the $1 \mathrm{wt} \% \mathrm{Mg}$ - HAp-Ws/PDLLA films may result from the $\mathrm{Mg}^{2+}$ ions produced by $\mathrm{Mg}$ - HAp-Ws/PDLLA) films. As the $\mathrm{Mg}^{2+}$ ion substitution was increased to $5 \mathrm{wt} \%$, cell spreading on the corresponding Mg-HAp-Ws/PDLLA composite films decreased. These findings are in agreement with the data of the present study showing the beneficial effect of $\mathrm{Mg}^{2+}$ ion of a low MgO concentration on HDPCs. However, higher concentrations of $\mathrm{MgO}$ had lower effect on attachment compared to the optimal concentration $(0.5 \mathrm{mM})$. Those results confirm with the present data demonstrating the essential role of $\mathrm{MgO}$ in HDPCs adhesion.

In the present study, proliferation rate of HDPCs was upregulated as noticed during the entire experiment time points when the supplemented $\mathrm{MgO}$ values were $0.5 \mathrm{mM}$. These results are in accordance with the reports by $[49,50]$ showing an up-regulatory effect on proliferation of an osteoblast -like cell line (MG63) in the presence of extracts of soluble phosphate glasses $\left(\mathrm{SiO}_{2}-\mathrm{CaO}-\mathrm{MgO}-\mathrm{P}_{2} \mathrm{O}_{5}\right)$ containing $\mathrm{MgO}$, also showing that $\mathrm{MgO}$ forms a suitable substrate for human osteoblast-like cell proliferation and function. [51] proposeda MgO-modified silicate bioglass (BGMIX-Mg) which was able to exert a strong stimulating effect on osteocyte growth (MLO-Y4). Other studies confirmed the accelerated growth of MG-63 cells on polysaccharide gelan gum (GG) hydrogel containing $\mathrm{MgO}$ [52]. Notably, Pallivi et al. [53] reported that $1 \mathrm{mM}$ concentration of $\mathrm{MgO}$, showed an enhancement of cell growth of human fetal osteoblasts (hFOB 1.19). These findings advocated that proliferation of cells was enhanced by the low $\mathrm{MgO}$ concentration supplements which is consistent with the results of the present study that was performed the first time on human dental pulp cells (HDPCs). In this study on HDPCs, $\mathrm{MgO}$ concertation higher than $0.5-8 \mathrm{mM}$ showed a down regulatory effect on cell proliferation rate. These results are in agreement with previous studies [49, 53-56], that reported inhibiting effects by higher $\mathrm{Mg}^{2+}$ concentrations on the proliferation activity of normal human osteoblasts, hFOB 1.19 cells, MG63 and MC3T3-E1 cell lines. Despite the fact of using normal human osteoblasts, various cell lines, and human pulp cells, all cell types showed a similar behavior responding to the optimal $\mathrm{Mg}^{2+}$ ion concentration. This paper provides the evidence implicating the role of $\mathrm{Mg}^{2+}$ ion as an important modulator of cell growth on normal human cells suggesting that $\mathrm{Mg}^{2+}$ ion actions are tightly regulated. Higher $\mathrm{Mg}^{2+}$ concentrations in the culture medium might interfere with the ion balance in the plasma membrane, leading to cytotoxicity and therefore inhibiting cellular proliferation and differentiation activities [57].

Analyzing the role of $\mathrm{MgO}$ biomaterials on cell viability of HDPCs is essential for elucidating the underlying molecular mechanisms. Cytotoxicity tests (MTT assay) can provide an initial indication of the biocompatibility of released metal cations. In the present study, $0.5 \mathrm{mM} \mathrm{MgO}$ concentration supplements seemed to have the same metabolic activity as the negative control on HDPCs. However, when the concentrations of supplement $\mathrm{MgO}$ were increased higher than $0.5 \mathrm{mM}$, cell viability decreased significantly. The result demonstrated that low MgO supplements had minimal cytotoxicity allowing HDPCs to attach and interact with the cells in a controlled manner. However, MgO concentrations higher than $0.5 \mathrm{mM}$ showed lower SDH activity values compared to the negative control. It can be postulated that the microenvironment where the cells reside can be affected by ions arising from the material dissolution affecting cell behavior [58]. Previous studies have shown that an increment in $\mathrm{Mg}^{2+}$ ion concentration caused by $\mathrm{MgO}$ degradation forms a high osmotic pressure, and that the alkaline environment caused by released hydroxide ions may leak gradually to the culture cells causing severe cytotoxicity.

The ALP activity data of the present study are in accordance with [50], [59,60] whom investigated the stimulatory effects of low MgO concentration on MG63 cells cultured on bioactive $\mathrm{SiO}_{2}-\mathrm{CaO}-\mathrm{P}_{2} \mathrm{O}_{5}-\mathrm{MgO}$ glass. A twofold increase in ALP activity was observed for the MG63 cells grown on the glass surfaces in comparison with that of the $\mathrm{MgO}$ free glass (control). Similarly, [42] proposed microsphere (PMg) prepared from poly (lactide-co-glycolide) (PLGA) coembedded with $\mathrm{MgO}$. PMg- microspheres (MgO 1 wt \%) upregulated osteogenic differentiation and high ALP activity 
levels of bone marrow mesenchymal stromal cells (BMMSCs. [48], studied osteogenic differentiation of MC3T3-E1 cells cultured on magnesium hydroxyapatite whiskers/poly (D, L-lactide) (Mg- HAp-Ws/PDLLA) compared with that of the HAp-Ws/ PDLLA (control) film. 1 wt \% Mg-HAp-Ws/ PDLLA film led to an up-regulation of ALP expression in MC3T3-E1 cells. Though a difference in cell type is noted among these experimental studies, ALP expression results in the present paper similarly coincide to those data at similar time point periods as ALP activity increased significantly on all the substrates after 7 days of culture, followed by an increase in its level between 7 and 14 days. However, the data of the present study also showed that the $\mathrm{MgO}$ concentrations higher than $0.5 \mathrm{mM}$ hindered ALP expression level. These results are in agreement with $[48,60]$ whom reported that excessive extracellular $\mathrm{Mg}^{2+}$ ion can restrain the differentiation ability of MC3T3-E1 and human osteosarcoma (MG-63) cell lines respectively. With higher $\mathrm{MgO}$ concentration, $\mathrm{Mg}^{2+}$ ions created may locally distort the double helix due to covalent bonding with DNA and may in turn affect the proliferation and differentiation of HDPCs [61]. In this study, it was noticed that the results of the assays of ALP activity and mineralization revealed a consistent pattern for the same concentrations at the same time points in HDPCs.

In the present study, adding an optimal concentration of supplemented $\mathrm{MgO}(0.5 \mathrm{mM})$ at time intervals of 7, 10 and 14 days had an upregulating effect on HDPCs, increasing mineralization and calcium deposition which are in accordance with [42] whom concluded that biodegradable polylactide-coglycolide (PMg-III) microspheres containing $1 \mathrm{wt} \% \mathrm{MgO}$ exhibited the strongest promotion of mineral depositions of BMSCs. Similarly, in a study by [62] poly (l-lactide) (PLLA) matrix, grafted with $1 \% \mathrm{MgO}$ whiskers (gMgOs) whiskers showed a large number of calcium deposition nodules on the surfaces of the scaffolds compared to reduced numbers of nodules on the neat PLLA scaffold by day 14 . These studies also found that the presence of $\mathrm{gMgOs}$ was more beneficial to mouse embryo osteoblast precursor (MC3T3) cells which revealed the superior osteogenic differentiation, secretion of ALP activity and mineralization ability of scaffold. The above forementioned studies proposed that the dissolution of $\mathrm{MgO}$ provided $\mathrm{Mg}^{2+}$ ion enabling nucleation sites for mineral growth, and highlighted that low levels of $\mathrm{Mg}^{2+}$ ion (1wt\%) concentration upregulated mineralization, clearly denoting the $\mathrm{MgO}$ concentration-dependent behavior [42,62]. On the other hand, in the present study, MgO concentrations higher than $\geq 0.5 \mathrm{mM}$ down regulated calcium deposition. These results are in agreement with [63,64,65], [54,66], [42], whom demonstrated that $\mathrm{Mg}^{2+}$ concentration over $1.3 \mathrm{mM}$ significantly suppressed mineralizing capacity of hBMSCs, vascular smooth muscle cells (VSMCs) chondrogenic cells (ATDC5), U2-OS, SaOS-2cells and human osteoblasts respectively. Furthermore, other studies have claimed that excessive $\mathrm{Mg}^{2+}$ may result in hypermagnesemia (a serum $\mathrm{Mg}^{2+}$ level exceeding $1.1 \mathrm{mM}$ ) which has physiological or pathological relevance. In this study, it was noticed that the results of the assays of ALP activity and mineralization revealed a consistent pattern for the same concentrations at the same time points in normal HDPCs, a cell type different from all other cell types of studies above forementioned studies.

The vehicle controls (lignin sulfonic acid disodium salt and xanthan gum) used in the present study imparted a significant role upregulating attachment efficiency, proliferation rates and inducing differentiation in HDPCs. Conforming the role of these vehicles on different biological activities of HDPCs in vitro contradicted the notion of the inert character of these vehicles [67]. Reported that the addition of lignin sulfonic acid disodium salt to a poly (lactic acid) matrix allowed tailoring of the final properties of the composites without inducing any significant change in cell metabolic activity compared to poly (lactic acid) itself. In vitro studies by $[68,69]$ whom investigated the effect of addition of lignin in prepared PLLA/PLA-lignin composites and in poly (vinyl alcohol) (PVA)-poly (glycerol sebacate) (PGS) fibers respectively on PC12 (rat phaeochromocytoma) cells. The studies revealed that the presence of lignin resulted in higher cell proliferation values of PC12 cells indicating their potential role in nerve tissue engineering. In a study by [70] a thermo-reversible hydrogel composed of xanthan gum-konjac glucomannan (at different concentrations ( $1 \%$ and $2 \% \mathrm{w} / \mathrm{v}$ ) and ratios (50/50 and $60 / 40$ ) was developed. They demonstrated the potential of XG/ KGM hydrogels to improve the wound healing process by promoting fibroblast migration, adhesion, and proliferation. Similarly [71], developed hybrid scaffolds of xanthan and magnetite $(X C A / m a g)$ whom noted that adhesion rates were more pronounced when cells were seeded on XCA/mag than on neat XCA or plastic dishes; XCA/mag and XCA hydrogels are scaffolds with distinguishable performance for adhesion and differentiation of embryonic stem cell (ESCs) into neurons.

The data presented in this study showed the beneficial effect of $\mathrm{MgO}$ on the various biological properties of HDPCs. By virtue of $\mathrm{MgO}$ bioactivity, extensive research has been conducted on $\mathrm{MgO}$ doped bioglass, calcium phosphate cement, in in vivo osteogenesis and bone remodeling [72]. Lack of $\mathrm{MgO}$ composites in dental applications has raised the interest for the present study aiming at producing $\mathrm{MgO}$ with biologic performance tailored for this specific clinical application. Questions have been raised regarding the extent and rate of solubility, degradation rate, associated structural stability, adequate reactivity, and feasibility for clinical use. In the present work enhancing solubility of $\mathrm{MgO}$ by the combined use oflignin sulfonic acid sodium salt and xanthan gum, provided a highly stable suspension combining the regenerative potential of $\mathrm{MgO}$ with the specific biological advantages. In fact, the application of $\mathrm{MgO}$ for dental tissue engineering is just at the beginning. A great deal of research is still needed to develop superior, straight-forward effective dopant chemistry modification methods to facilitate the full use of biodegradable and improved bio-functional material for dental tissue regeneration.

\section{Conclusion}

The data presented in this study suggested the beneficial effect of $0.5 \mathrm{mM} \mathrm{MgO}$ on the various biological properties of HDPCs leading to a potential of an improved pulp capping 
material. This is the first report to demonstrate the optimal $\mathrm{MgO}$ concentration needed to significantly enhance the dentinogenic activities of HDPCs.

\section{Conflict of Interests:}

The authors declare no conflict of interests.

\section{References}

1. Murray PE, Garcia-Godoy F, Hargreaves KM. Regenerative endodontics: A review of current status and a call for action. J Endod. 2007; 33(4): 377390. doi: 10.1016/j.joen.2006.09.013

2. Mitsiadis TA, Woloszyk A, Jimenez-Rojo L. Nanodentistry: Combining nanostructured materials and stem cells for dental tissue regeneration. Nanomedicine. (London, England). 2012; 7(11): 1743-1753. doi: 10.2217/ nnm.12.146

3. Polesel A. Restoration of the endodontically treated posterior tooth. Giornale Italiano di Endodontia. 2014; 28(1): 2-16. doi: 10.1016/j. gien.2014.05.007

4. Bjørndal L, Simon S, Tomson LP, Duncan HF. Management of deep caries and the exposed pulp. Int Endod J. 2019; 52(7): 345-34. doi: 10.1111/iej.13128

5. George T, Huang J. Dental Pulp and Dentin Tissue Engineering and Regeneration - Advancement and Challenge. Front Biosci (Elite Edi). 2011; 1(3): 788-800. doi: 10.2741/e286

6. Moussa DG, Aparicio C. Present and future of tissue engineering scaffolds for dentin-pulp complex regeneration. J Tissue Eng Regen Med. 2019; 13(1): 58-75. doi: 10.1002/term.2769

7. Smith A. Vitality of the Dentin-Pulp Complex in Health and Disease: Growth Factors as Key Mediators. J Dent Educ. 2003; 67(6): 678-89.

8. Sun HH, Jin T, Yu Q, Chen FM. Biological approaches toward dental pulp regeneration by tissue engineering. J Tissue Eng Regen Med. 2011; 5(4): e1-16.

9. Asgary $\mathrm{S}$, Nazarian $\mathrm{H}$, Khojasteh A, Shokouhinejad N. Gene expression and cytokine release during odontogenic differentiation of human dental pulp stem cells induced by 2 endodontic biomaterials. J Endod. 2014; 40(3): 387-392. doi: 10.1016/j.joen.2013.09.017

10. Thomas Catala CJ, Collado-Gonzalez M, Garcia-Bernal D, et al. Biocompatibility of New Pulp-capping Materials NeoMTA Plus, MTA Repair HP, and Biodentine on Human Dental Pulp Stem Cells. J Endod. 2018; 44 (1): 126-132. doi: 10.1016/j.joen.2017.07.017

11. Park SJ, Heo SM, Hong SO, et al. Odontogenic effect of a fast-setting pozzolan-based pulp capping material. J Endod. 2014; 40(8): 1124-1131. doi: 10.1016/j.joen.2014.01.004

12. Zhu L, Yang J, Zhang J, Peng B. A comparative study of BioAggregate and ProRoot MTA on adhesion, migration, and attachment of human dental pulp cells. J Endod. 2014; 40(8): 1118-11123. doi: 10.1016/j. joen.2013.12.028

13. Sequeira DB, Seabra CM, Palma PJ, Cardos Peça J, Santos J. Effects of a New Bioceramic Material on Human Apical Papilla Cells J Funct. Biomater. 2018; 16(9): 74: doi: 10.3390/jfb9040074

14. Chen FM, Liu X. Advancing biomaterials of human origin for tissue engineering. Prog Polym Sci. 2016; 1(53): 86-168. doi: 10.1016/j. progpolymsci.2015.02.004

15. Murphy WL, McDevitt TC, Engler AJ. Materials as stem cell regulators. Nat Mater. 2014; 13(6): 547-557. doi: 10.1038/nmat3937

16. Lange TS, Kirchberg J, Bielinsky AK, et al. Divalent cations $\left(\mathrm{Mg}^{2+}, \mathrm{Ca}^{2+}\right)$ differentially influence the beta 1 integrin-mediated migration of human fibroblasts and keratinocytes to different extracellular matrix proteins. Exp Dermatol. 1995; 4(3): 130-7. doi: 10.1111/j.1600-0625.1995.tb00236.x

17. Albelda SM, Buck CA. Integrins and other cell adhesion molecules. FASEB J. 1990; 4(11): 2868-2880.

18. Zhang $\mathrm{K}$, Chen JF. The regulation of integrin function by divalent cations.
J Cell Adh Migr. 2012; 1(6): 20-29. doi: 10.4161/cam.18702

19. Wiesmann HP, Tkotz $T$, Joos $U$, et al. Magnesium in Newly Formed Dentin Mineral of Rat Incisor. J Bone Miner Res.1997; 12(3): 380-383. doi: 10.1359/jbmr.1997.12.3.380

20. Wu L, Feyerabend F, Schilling A, Willumeit R. Effects of extracellular magnesium extract on the proliferation and differentiation of human osteoblasts and osteoclasts in coculture. Acta Biomater. 2015; 27(2): 294-304. doi: 10.1016/j.actbio.2015.08.042

21. He $L Y$, Zhang $X M, M a W H$. Effect of magnesium ion on human osteoblast activity. Braz J Med Biol Res. 2016; 49(7): 5257: e1-6. doi: 10.1590/1414431X20165257

22. Jin W, Jiang S, Pan H, Tang R. Amorphous Phase Mediated Crystallization: Fundamentals of Biomineralization. Crystals. 2018; 8(48): 1-24. doi $10.3390 /$ cryst8010048

23. Silva LM Da, Tavares $\mathrm{D}$, Santos EAD. Isolating the Effects of $\mathrm{Mg}^{2+,} \mathrm{Mn}^{2+}$ and $\mathrm{Sr}^{2+}$ lons on Osteoblast Behavior from those Caused by Hydroxyapatite Transformation. J Materials Research. 2020; 23(2): 1-10 doi: 10.1590/1980-5373-MR-2020-0083

24. Wu X, Dai $\mathrm{H}, \mathrm{Yu}$, et al. Magnesium Calcium Phosphate Cement Incorporating Citrate for Vascularized Bone Regeneration. ACS Biomater Sci Eng. 2020; 6(11): 6299-6308. doi: 10.1021/acsbiomaterials.0c00929

25. Ma FQ, Lu XL, Wang ZM, et al. Nanocomposites of poly(L-lactide) and surface modified magnesia: Fabrication, mechanical property and biodegradability. J Phys Chem Solids. 2011; 72(2): 111-116. doi: 10.1016/j. jpcs.2010.11.008

26. Wen $W$, Zou ZP, Luo BH, Zhou CR. In vitro degradation and cytocompatibility of $\mathrm{g}-\mathrm{MgO}$ whiskers/PLLA composites. J Mater Sci. 2017; 52 (4): 2329-2344.

27. Zhao $Y$, Liang $H$, Chen M. Effects of Magnesium Oxide (MgO) Shapes on In Vitro and In Vivo Degradation Behaviors of PLA/MgO Composites in Long Term. Polymers (Basel). 2020; 12(15): 1-13.

28. Yoshizawa S, Brown A, Barchowsky A, Sfeir C. Role of magnesium ions on osteogenic response in bone marrow stromal cells. Connect Tissue Res. 2014; 55(S1): 155-159. doi: 10.3109/03008207.2014.923877

29. Richard H, Van de Walle. Concentrated suspension of aqueous magnesium oxide. Patent number: 4834957, Filed: April 21, 1987, Date of Patent: May 30, 1989, Assignee: Martin Marietta Corporation.

30. Raoof $M$, Yaghoobi MM, Derakhshani $A$, et al. A modified efficient method for dental pulp stem cell isolation. Dent Res J (Isfahan). 2014; 11(2): 244-50.

31. Mosmann T. Rapid colorimetric assay for cellular growth and survival: Application to proliferation and cytotoxicity assays. J Immunol Methods. 1983; 65(1): 55-63. doi: 10.1016/0022-1759(83)90303-4

32. Zhang W, Yelick PC. Vital pulp therapy-current progress of dental pulp regeneration and revascularization. Int J Dent. 2010; 856087: 1-9. doi: $10.1155 / 2010 / 856087$

33. Potdar PD, Jethmalani YD. Human dental pulp stem cells: Applications in future regenerative medicine. World J stem cells. 2015; 7(5): 839-851. doi: $10.4252 /$ wjsc.v7.i5.839

34. Li TX, Yuan J, Chen Y, et al. Differentiation of mesenchymal stem cells from human umbilical cord tissue into odontoblast- like cells using the conditioned medium of tooth germ cells in vitro. Bio Med Res Int. 2013 218543: 1-10. doi: 10.1155/2013/218543

35. Poggio C, Ceci M, Beltrami R, Dagna A, Colombo M, Chiesa M. Biocompatibility of a new pulp capping cement. Ann Stomatol (Roma). 2014; 5(2): 69-76.

36. Morotomi T, Washio A, Kitamura C. Current and future options for dental pulp therapy. Jpn Dent Sci Rev. 2019; 55(1): 5-11. doi: 10.1016/j. jdsr.2018.09.001

37. Glenske K, Donkiewicz P, Barbeck $M$, et al. Applications of Metals for Bone Regeneration Int J Mol Sci. 2018; 19(826): 1-32. doi: 10.3390/ ijms19030826 
38. Zreiqat $H$, Howlett $C R$, Wu Y, McFall DW, McKenzie DR. Effect of ion modification of commonly used orthopedic materials on the attachment of human bone-derived cells. J Biomed Mater Res. 1999; 45(4): 345-354. doi: 10.1002/(sici)1097-4636(19990615)45:4<345::aid-jbm9>3.0.co;2-j

39. Zreiqat $H$, Bilek MMM, Evans P, McKenzie DR, Mcculloch DG, Howlett CR. Metal ion implantation using a filtered cathodic vacuum arc. J Appl Physics. 2000; 87(9): 4198-4204. doi: 10.1063/1.373052

40. Shimaya $M$, Muneta $T$, Ichinose $S$, et al. Magnesium enhances adherence and cartilage formation of synovial mesenchymal stem cells through integrins. Osteoarthritis Cartilage. 2010; 18(10): 1300-1309. doi: 10.1016/j.joca.2010.06.005

41. Bae HY, Park HJ, Wang SY, et al. Hypoxic condition enhances chondrogenesis in synovium- derived mesenchymal stem cells. Biomater Research. 2018; 22(28): 1-14. doi: 10.1186/s40824-018-0134-x

42. YuanZ, Wei P, Huang Y, et al. Injectable PLGA microspheres with tunable magnesium ion release for promoting bone regeneration. Acta Biomater. 2019; 85(2): 294-309. doi: 10.1016/j.actbio.2018.12.017

43. Zhang K, Sun Z, Liu S. Recent Developed Strategies for Enhancing Chondrogenic Differentiation of MSC: Impact on MSC-Based Therapy for Cartilage Regeneration. Stem Cells International. 2021; 8830834: 1-15. doi: 10.1155/2021/8830834

44. Howlett $C R$, Chen N, Zhang $X$, et al. Effect of biomaterial chemistries on the osteoblastic molecular phenotype and osteogenesis: in vitro and in vivo studies. In: JE Davies, editor. Bone tissue engineering. Toronto: Em Squared Incorporated. 2000; 240- 255.

45. Zreiqat $H$, Howlett $C R$, Zannettino $A$, et al. Mechanisms of magnesiumstimulated adhesion of osteoblastic cells to commonly used orthopaedic implants. J Bio Med Mater Res. 2002; 62 (2): 175-84. doi: 10.1002/jbm.10270

46. Saito $T$, Albelda SM, Brighton CT. Identification of integrin receptors on cultured human bone cells. J Orthop Res. 1994; 12(3): 384- 394. doi: 10.1002/jor.1100120311

47. Sana FA, Yurtsever MC, Bayrak GK, et al. Spreading, proliferation and differentiation of human dental pulp stem cells on chitosan scaffolds immobilized with RGD or fibronectin. Cytotechnology. 2017; 69(4): 617630. doi: 10.1007/s10616-017-0072-9

48. Li W, Lu Y, Liu K, et al. Preparation of HAp whiskers with or without Mg ions and their effects on the mechanical properties and osteogenic activity of poly (d,l-lactide). Composite Part B. 2020; 196(1): 1-13. doi: 10.1016/j.compositesb.2020.108137

49. Franks $\mathrm{K}$, Salih $\mathrm{V}$, Knowles JC. The effect of $\mathrm{MgO}$ on the solubility behavior and cell proliferation in a quaternary soluble phosphate-based glass system. J Mater Sci: Mater Med. 2002; 13(6): 549-556. doi: 10.1023/a:1015122709576

50. Balamurugan A, Balossier G, Michel J, Sanjeevi K. Sol gel derived SiO2$\mathrm{CaO}-\mathrm{MgO}-\mathrm{P} 2 \mathrm{O} 5$ bioglass system-Preparation and in vitro characterization. J Biomed Mater Res B Appl Biomater. 2007; 83(2): 546-5. doi: 10.1002/jbm.b.30827

51. Bellucci D, Sola A, Salvatori R, Anesi A, Chiarini L, Cannillo V. Role of magnesium oxide and strontium oxide as modifiers in silicate-based bioactive glasses: Effects on thermal behaviour, mechanical properties and in-vitro bioactivity. Material Science and Engineering. 2017; 1(72): 566-575. doi: 10.1016/j.msec.2016.11.110

52. Douglas TEL, Lapa A, Reczyńska K, Krok M. Novel injectable, self-gelling hydrogel-microparticle composites for bone regeneration consisting of gellan gum and calcium and magnesium oxide carbonate microparticles. BioMed Mater. 2016; 11(6):065011. doi: 10.1088/1748-6041/11/6/065011

53. Pallavi M, Waterman J, Koo Y, Sankar J, Yun Y. In Vitro Cytotoxicity of Possible Corrosion Products from Mg-Based Biodegradable Metals: Magnesium Oxide and Magnesium Hydroxide Nanoparticles. Appl Sci. 2019; 9(20): 1-15. doi: 10.3390/app9204304

54. Leidi M, Dellera F, Mariotti M, Maier JA. High magnesium inhibits human osteoblast differentiation in vitro. Magnes Res. 2011; 24(1): 1-6. doi: 10.1684/mrh.2011.0271

55. Kircelli F, Peter ME, Sevinc $O E$, et al. Magnesium reduces calcification in bovine vascular smooth muscle cells in a dose-dependent manner Nephrol Dial Transplant. 2012; 27(2): 514-521. doi: 10.1093/ndt/gfr321

56. Lu WC, Pringa $E$, Chou L. Effect of magnesium on the osteogenesis of normal human osteoblasts. J Magnes Res. 2017; 30(2): 42-52. doi: $10.1684 / \mathrm{mrh} .2017 .0422$

57. Tam M, Gomez S, Gonza 'lez- GM, Marcos A. Possible roles of magnesium on the immune system. Eur J Clin Nutr. 2003; 57(10): 1193-1197. doi: 10.1038/sj.ejcn.1601689

58. Lima FDS, Fock RA. Review of the Action of Magnesium on Several Processes Involved in the Modulation of Hematopoiesis. Int J Mol Sci. 2020; 21(19): 7084: 1-22. doi: 10.3390/ijms21197084

59. Saboori A, Rabiee M, Moztarzadeh F, Sheikhi M. Synthesis, characterization, and in vitro bioactivity of sol-gel-derived $\mathrm{SiO} 2-\mathrm{CaO}-\mathrm{P} 2 \mathrm{O} 5-\mathrm{MgO}$ bioglass. Materials Science and Engineering C. 2009; 29(1): 335-340. doi:10.1016/j. msec.2008.07.004

60. Rezaei Y, Moztarzadeh F, Shahabi S, Tahriri M. Synthesis, Characterization, and In vitro Bioactivity of Sol-Gel-Derived SiO2-CaO-P2O5-MgO-SrO Bioactive Glass. Synthesis and Reactivity in Inorganic, Metal-Organic, and NanoMetal Chemistry. 2013; (44): 692-701. doi: 10.1080/15533174.2013.783869

61. Every $A E$, Russu IM. Influence of Magnesium lons on Spontaneous Opening of DNA Base Pairs. J Phys Chem B. 2008; 112(25): 7689-7695. doi: $10.1021 /$ jp8005876

62. Liu K, Li W, Chen S, et al. The design, fabrication and evaluation of 3D printed $g \mathrm{HNTs} / \mathrm{gMgO}$ whiskers/PLLA composite scaffold with honeycomb microstructure for bone tissue engineering. Composites Part B: Engineering. 2020; 192(10): 1-15 108001.63. doi: 10.1016/j. compositesb.2020.108001

63. Nakatani S, Mano H, Ryanghyok IM, Shimizu J, Wada M. Excess magnesium inhibits excess calcium-induced matrix-mineralization and production of matrix gla protein (MGP) by ATDC5 cells. Biochem Biophys Res Commun. 2006; 348(3): 1157-62. doi: 10.1016/j.bbrc.2006.07.180

64. Montezano AC, Zimmerman D, Yusuf $\mathrm{H}$, et al. Vascular Smooth Muscle Cell Differentiation to an Osteogenic Phenotype Involves TRPM7 Modulation by Magnesium. Hypertension. 2010; 56(3): 453-462. doi: 10.1161/HYPERTENSIONAHA.110.152058

65. Yun YH, Dong Z, Tan Z, Schulz M. Development of an electrode cell impedance method to measure osteoblast cell activity in magnesiumconditioned media. Anal Bioanal Chem. 2010; 396(8): 3009-15. doi: 10.1007/s00216-010-3521-2

66. Zhang $L$, Yang $C$, Li J, Zhu Y, et al. High extracellular magnesium inhibits mineralized matrix deposition and modulates intracellular calcium signaling in human bone marrow-derived mesenchymal stem cells. Biochem Biophys Res Commun. 2014; 450(4): 1390-5. doi: 10.1016/j. bbrc.2014.07.004

67. Zhai S, Liu Q, Zhao Y, Sun H, Yang B, Weng Y. A Review: Research Progress in Modification of Poly (Lactic Acid) by Lignin and Cellulose. Polymers. 2021; 13(5): 776 doi: 10.3390/polym13050776

68. Kai D, Tan MJ, Chee PL, Chua YK, Yap YL, Loh XJ. Towards lignin-based functional materials in a sustainable world. Green Chem. 2016; 18(5): 1175-1200. doi: 10.1039/C5GC02616D

69. Saudi A, Rafienia M, Kharazi AZ, Salehi H, Zarrabi A, Karevan M. Design and fabrication of poly (glycerol sebacate)-based fibers for neural tissue engineering: Synthesis, electrospinning, and characterization. Polymers Advanced Technologies. 2019; 30(6): 1427-1440. doi: 10.1002/pat.4575

70. Alves A, Miguel SP, Coutinho P, et al. Xanthan Gum-Konjac Glucomannan Blend Hydrogel for Wound Healing. Polymers. 2020; 12(1): 1-15. doi: 10.3390/polym12010099

71. Glaser T, Bueno VB, Cornejo DR, Petri DVS, Ulrih C. Neuronal adhesion, proliferation, and differentiation of embryonic stem cells on hybrid scaffolds made of xanthan and magnetite nanoparticles. Biomed Mater. 2015; 10(4): 1-13: doi: 10.1088/1748-6041/10/4/045002

72. Sergi R, Bellucci D, Cannillo VA. Review of Bioactive Glass/Natural Polymer Composites: State of the Art. Materials. 2020; 13(23): 1-38. 5560 doi: 10.3390/ma13235560 